\title{
PEMBERDAYAAN UMKM MELALUI KOPERASI PADA KECAMATAN LEUWIDAMAR, KABUPATEN LEBAK, BANTEN
}

\author{
Suharyati $^{1}$, Ediwarman $^{2}$, dan Nobelson $^{3}$ \\ ${ }^{1}$ Jurusan Manajemen, Fakultas Ekonomi dan Bisnis UPN Veteran Jakarta \\ Email: suharyati@upnvj.ac.id \\ ${ }^{2}$ Jurusan Manajemen, Fakultas Ekonomi dan Bisnis UPN Veteran Jakarta \\ Email: ediwarman.upnvj@gmail.com \\ ${ }^{3}$ Jurusan Manajemen, Fakultas Ekonomi dan Bisnis UPN Veteran Jakarta \\ Email: nobelsonsyarief1160@gmail.com
}

\begin{abstract}
The era of globalization and digitalization have the impact of narrowing the space for cooperatives and fierce competition. Cooperatives contribute to the Indonesian economy, and to improve people's welfare. The activity of empowering MSMEs through cooperatives is expected to be able to contribute to optimizing MSMEs. The participants of the activity were 30 craftsmen in Kanekes village, Leuwidamar sub-district. Activities carried out by lectures and discussions method about the roles and benefits of cooperatives for MSMEs. Participants were also given a questionnaire to fill in demographic data and a test of understanding of cooperatives. Based on the results, it was found that the largest number of participants were at the productive age, had a typical Baduy business. The business is a home business with an average number of employees of two people who are family members. The amount of capital is in the range of IDR 10,000,000 to 25,000,000 in the form of own capital. The monthly income received is $\leq$ 1.000.000,- because the business is on a micro-scale. Business age $\leq 2$ years, the training participants are relatively new business actors. As for financial services through cooperatives, $77 \%$ of participants did not use them. The test results show an understanding of cooperatives by $86 \%$ and an interest in becoming a cooperative member by $80 \%$, which means that after being given provisioning, the participants really understand the role of cooperatives for MSMEs and are interested in becoming cooperative members.
\end{abstract}

Keywords: Cooperatives, MSME, Empowerment

\begin{abstract}
ABSTRAK
Era globalisasi dan digitalisasi cenderung memiliki dampak mempersempit ruang gerak koperasi, dan persaingan ketat. Koperasi berkontribusi bagi perekonomian Indonesia, dan merupakan wadah untuk meningkatkan kesejahteraan masyarakat. Kegiatan pemberdayaan UMKM melalui koperasi ini diharapkan mampu memberikan kontribusi dalam mengoptimalkan UMKM untuk berpartisipasi pada koperasi. Peserta kegiatan adalah pengrajin di desa Kanekes, kecamatan Leuwidamar sebanyak 30 orang. Kegiatan dilaksanakan dengan metode ceramah dan diskusi mengenai peran dan manfaat koperasi bagi UMKM. Pada akhir kegiatan peserta diberikan kuesioner untuk mengisi data demografi dan test pemahaman mengenai perkoperasian. Berdasarkan hasil deskripsi data peserta diperoleh jumlah terbesar usia peserta berada pada usia produktif, memiliki usaha kerajinan khas suku baduy, seperti kain tenun, tas koja, souvenir. Usaha yang dilakukan berupa usaha rumahan dengan jumlah karyawan rata-rata dua orang yang merupakan anggota keluarga. Jumlah modal pada kisaran Rp.10.000.000,- s/d 25.000.000,- berupa modal sendiri. Pendapatan yang diterima perbulan $\leq 1.000 .000$,- karena usaha yang dilakukan berada pada skala mikro. Usia usaha $\leq 2$ tahun, peserta pelatihan merupakan pelaku usaha yang relatif baru. Sedangkan untuk layanan keuangan melalui koperasi sebesar $77 \%$ peserta tidak menggunakan. Hasil test menunjukkan pemahaman mengenai perkoperasian sebesar $86 \%$ dan minat untuk menjadi anggota koperasi sebesar $80 \%$, yang berarti setelah diberikan pembekalan peserta sangat memahami peran koperasi bagi UMKM dan berminat menjadi anggota koperasi.
\end{abstract}

Kata Kunci: Koperasi, UMKM, Pemberdayaan

\section{PENDAHULUAN}

\section{Latar Belakang}

Era globalisasi dan digitalisasi, membuka peluang sekaligus tantangan bagi dunia usaha seiring dengan meningkatnya kemajuan teknologi di berbagai bidang. Dimensi globalisasi, memberi manfaat melalui peningkatan pertumbuhan ekonomi, kenaikan pendapatan per kapita dan 
penurunan kemiskinan, namun globalisasi juga telah meningkatkan kepekaan berbagai guncangan dan dampak negatif globalisasi (Setiawan, 2018). Hal ini tentunya berdampak bagi kegiatan usaha Koperasi. Era globalisasi dan teknologi ini cenderung memiliki implikasi yang berdampak mempersempit ruang gerak koperasi, diantaranya adalah kompetisi yang semakin meningkat, namun demikian berbagai tantangan, ancaman, dan hambatan yang terjadi. Bila koperasi dan semua pihak mau dan mampu menganalisa semua kekuatan dan kelemahan yang dimiliki koperasi dengan tepat, maka bukan tidak mungkin berbagai tantangan, ancaman, dan hambatan tersebut justru dapat menjadi faktor pendukung terbukanya peluang usaha yang positif bagi gerakan koperasi dan ekonomi rakyat pada umumnya, (Multi Inti Sarana Group, 2019).

Koperasi merupakan wadah untuk meningkatkan kesejahteraan masyarakat, karena itu koperasi dapat pula menjalankan perannya sebagai pemberdaya masyarakat atau pelaku UMKM, dengan sasaran masyarakat ekonomi lemah atau masyarakat kurang berdaya, (Mustangin et al., 2018; Nailufar, 2020; Pasal 33 UUD 1945). Pemberdayaan masyarakat melalui kegiatan koperasi unit desa ialah salah satu bentuk treatment yang dilakukan oleh masyarakat pedesaan dalam rangka menggerakkan roda perekonomian keluarga secara khusus dan pedesaan pada umumnya. (Rufaidah, 2017)

Saat ini kontribusi koperasi terhadap Pendapatan Domestik Bruto (PDB) terus menanjak dan mencapai 5,1\% pada 2018 (Rachmawati, 2019). Perkembangan koperasi mengalami peningkatan yang cukup baik, sejalan dengan itu pemerintah kota Bogor mendorong digitalisasi koperasi dan memberikan coaching clinic bagi koperasi. (mediaindonesia.com).

Pengembangan profesionalisme bagi koperasi memang tidak mudah mengingat masih banyak tingkat pendidikan yang masih rendah, namun mengingat peran koperasi turut memakmurkan masyarakat Indonesia, maka dibutuhkan partisipasi, dan uluran tangan berbagai pihak untuk memajukan perkoperasian Indonesia (Mulyono, 2010). Selanjutnya transformasi Koperasi di Indonesia perlu didukung dengan pengembangan Sumber Daya Manusia (SDM). Untuk mendorong keberhasilan pengembangan SDM koperasi, ada beberapa upaya yang perlu dilakukan. (1) dengan meningkatkan pelatihan perkoperasian secara masif. (2) sertifikasi kompetensi untuk pengelola koperasi. (3) bimbingan teknis dan pendampingan penyusunan strategi bisnis hingga pemasaran. (4) pengenalan koperasi mulai dari pendidikan dasar. (5) mendorong digital literacy, kreativitas, dan inovasi. (Niaga.Asia, 2019). Secara umum faktor penghambat bagi koperasi adalah faktor internal, seperti kurang memahami makna perkoperasian, masih banyak anggota koperasi yang beranggapan bahwa pengelolaan koperasi dipercayakan kepada pengurus. Hambatan faktor eksternal, diantaranya adalah modal koperasi yang terbatas, sulit untuk mendapatkan pinjaman, (Susilawetty \& Supena, 2013).

Berdasarkan informasi yang diterima tim pengabdi melalui beberapa tokoh masyarakat Baduy luar, serta dinas Koperasi dan UMKM Rangkasbitung, keberadaan koperasi di pemukiman Baduy luar belum memadai bahkan masyarakat Baduy belum memahami makna dari koperasi. Saat ini jumlah koperasi yang ada di kabupaten Lebak sejumlah 565 koperasi aktif, sedangkan jumlah koperasi yang beraktivitas di kecamatan Leuwidamar berjumlah 9 koperasi dan jumlah koperasi yang berada di desa Kanekes hanya 2 koperasi yaitu Koperasi Baduy Sejahtera dan Koperasi Fikri Sejahtera (depkop.go.id, 2020). Sedangkan jumlah penduduk desa Kanekes memiliki 11.669 jiwa, luas wilayah $51 \mathrm{~km}$ terdapat 351 pengrajin yang terbagi: 187 pengrajin tenun, 22 pengrajin kulit, 8 
pengrajin logam mulia, 106 pengrajin anyaman dan 28 pengrajin lainnya (BPS-Kabupaten-Lebak, 2018). Hal ini tentunya kurang memadai dibanding dengan jumlah penduduk dan luas wilayahnya.

Berdasarkan pada fenomena yang ada mengenai koperasi di kecamatan Leuwidamar, khususnya desa Kanekes, dan peran koperasi bagi masyarakat, maka keberadaan koperasi dirasakan kurang memadai. Dengan demikian masih terbukanya peluang untuk mendirikan koperasi sebagai wadah yang dapat memfasilitasi layanan keuangan serta pemasaran produk anggota. Atas dasar ini pula tim pengabdi tertarik untuk melakukan pengabdian kepada masyarakat dengan memberikan pemahaman dan pembekalan mengenai peran dan manfaat koperasi bagi masyarakat khususnya di desa Kanekes, serta menumbuhkan minat peserta untuk membentuk koperasi.

\section{Lokasi}

Lokasi kegiatan pengabdian kepada masyarakat ini berada di Kabupaten Lebak yang terdiri atas 28 kecamatan, yang dibagi atas 340 desa dan 5 kelurahan. Salah satu desa yang dijadikan sebagai objek pengabdian kepada masyarakat ini adalah desa Kanekes, kecamatan Leuwidamar yang merupakan perkampungan Baduy. Wilayah Kanekes, berada tepat di kaki pegunungan Kendeng di desa Kanekes, Kecamatan Leuwidamar, Kabupaten Lebak, Rangkasbitung, Banten yang berjarak sekitar $40 \mathrm{~km}$ dari kota Rangkasbitung (id.wikipedia.org). Perkampungan Baduy ini merupakan salah satu objek wisata yang dimiliki oleh Kabupaten Lebak dan sering dikunjungi wisatawan mancanegara karena memiliki keunikan tersendiri. Suku Baduy terbagi dalam 2 (dua) golongan yang disebut dengan Baduy Dalam dan Baduy Luar. Masyarakat Baduy Luar telah berinteraksi dengan kebudayaan luar selain Baduy. Kehidupan sehari-hari suku Baduy yaitu bercocok tanam, penghasil kerajinan seperti kain tenun, kain batik, tas koja, madu, dan pernakpernik souvenir dan setiap keluarga memiliki toko kerajinan Baduy di rumah tinggalnya.

Berdasarkan kondisi yang ada di pemukiman Baduy Luar di desa Kanekes ini, diperlukan suatu wadah bagi masyarakat untuk dapat mendukung perekonomian. Jumlah penduduk yang sebagian besar memiliki usaha sebagai pengrajin maupun petani memerlukan dukungan modal untuk meningkatkan produksinya dan dukungan sarana untuk pemasaran produk mereka. Koperasi merupakan wadah yang tepat untuk memfasilitasi kebutuhan modal dan pemasaran produk para pengrajin yang merupakan UMKM sektor mikro.

\section{Permasalahan}

Dengan melihat pentingnya upaya pemberdayaan masyarakat untuk meningkatkan kualitas hidup, kemandirian, dan kesejahteraan ekonomi maka diperlukan pendampingan dan keterlibatan pemerintah daerah maupun berbagai pihak termasuk perguruan tinggi untuk membantu mewujudkan peningkatan taraf hidup masyarakat. Salah satu bentuk pemberdayaan masyarakat ini dengan ikut berpartisipasi dalam koperasi. Kegiatan pengabdian kepada masyarakat ini diharapkan mampu memberikan kontribusi dalam mengoptimalkan peran dan kemampuan masyarakat dalam hal ini pelaku UMKM sebagai penunjang ekonomi keluarga maupun dalam dunia usaha dengan memanfaatkan layanan keuangan dan pemasaran produk melalui koperasi. Berdasarkan pada fenomena yang ada dan kurangnya jumlah koperasi di desa Kanekes, maka diperlukan kegiatan pengabdian kepada masyarakat dengan tema: "Pemberdayaan UMKM Melalui Koperasi di Desa Kanekes, Leuwidamar". Kegiatan ini dilakukan dengan cara pemberian pemahaman dan pembekalan kepada pengrajin desa Kanekes mengenai peran koperasi sebagai wadah kegiatan usaha UMKM dan sarana layanan keuangan serta permodalan serta menumbuhkan minat untuk berpartisipasi di koperasi. 


\section{Solusi Yang Ditawarkan}

Dalam penyelesaian masalah mengenai upaya pemberdayaan masyarakat ini, dilakukan dengan memberikan pemahaman dan pembekalan kepada pelaku UMKM Desa Kanekes, Leuwidamar, Kabupaten Lebak. Dengan ini pelaku UMKM dapat mengenal lebih jauh peran koperasi yaitu sebagai wadah kegiatan usaha UMKM dan sekaligus sarana pemasaran produk serta layanan keuangan simpan-pinjam dan permodalan UMKM guna meningkatkan kesejahteraan UMKM sebagai anggota koperasi serta menumbuhkan minat berkoperasi.

\section{METODE PELAKSANAAN PKM}

\section{Metode Pendekatan}

Pengabdian kepada masyarakat dengan tema: "Pemberdayaan UMKM melalui koperasi pada kecamatan Leuwidamar, kabupaten Lebak, Banten", dilakukan dengan cara memberikan pemahaman dan pembekalan tentang koperasi dan pemanfaatan layanan keuangan simpan pinjam bagi permodalan UMKM dengan metode ceramah, diskusi dan memberikan hand out materi pembekalan. Pada akhir pembekalan diberikan kuesioner yang berisi mengenai deskripsi data responden dan pemahaman atas materi yang diberikan. Jumlah peserta yang mengikuti kegiatan sebanyak 30 peserta. Peserta kegiatan adalah pengrajin di desa Kanekes yang memiliki usaha maupun yang tidak memiliki usaha. Jumlah peserta dibatasi karena kebijakan PSBB di masa pandemi Covid 19.

\section{Rencana Kegiatan}

Rencana kegiatan pengabdian kepada masyarakat ini, dilakukan dengan tahapan yaitu: melakukan perizinan, melakukan studi lapangan untuk mempelajari masalah yang menjadi permasalahan prioritas mitra, mempelajari pengaruh budaya setempat terhadap permasalahan masyarakat yang ada, melakukan kerjasama dengan Dinas Koperasi dan UMKM untuk melaksanakan program pengabdian kepada masyarakat sebagai solusi terhadap permasalahan prioritas mitra.

\section{Partisipasi Mitra}

Mitra berpartisipasi dalam pelaksanaan program pengabdian kepada masyarakat ini dari tahap awal hingga tahap akhir. Pada tahap awal perijinan pelaksanaan program pengabdian kepada masyarakat ini mitra berpartisipasi dalam: memberikan informasi tentang permasalahan yang dihadapi mitra, memberikan perijinan kepada Fakultas Ekonomi dan Bisnis Universitas Pembangunan Nasional Veteran Jakarta untuk melakukan studi lapangan pada wilayah mitra, menandatangani perizinan program pengabdian kepada masyarakat.

\section{Prosedur Kerja}

Untuk melaksanakan pembekalan dalam kegiatan pengabdian kepada masyarakat ini, diperlukan prosedur kerja agar lebih memudahkan dalam pelaksanaan pembekalan dan sekaligus untuk melakukan evaluasi kegiatan tersebut.

\section{Tabel 1}

\section{Prosedur Kerja}

\begin{tabular}{ccll}
\hline TAHAP & & \multicolumn{1}{c}{ KEGIATAN } & \multicolumn{1}{c}{ INDIKATOR } \\
\hline 1 & a. & Memberikan pemahaman tentang perkoperasian & Dilakukan test untuk \\
& b. & $\begin{array}{l}\text { Memberikan pemahaman tentang memanfaatkan layanan keuangan } \\
\text { menilai pencapaian }\end{array}$ & pegiatan dengan hasil \\
& c. & Minat untuk menjadi anggota koperasi & $>70 \%$ \\
\hline
\end{tabular}


2 Dalam kegiatan ini peserta mendengarkan ceramah dan melakukan

diskusi/tanya jawab

\section{Tabel 2}

\section{Instrumen Pengabdian Kepada Masyarakat Pemahaman Mengenai Perkoperasian}

\begin{tabular}{|c|c|c|}
\hline NO & BUTIR PERNYATAAN & Kode \\
\hline 1 & $\begin{array}{l}\text { Koperasi adalah badan usaha yang beranggotakan orang-seorang atau badan hukum Koperasi } \\
\text { dengan melandaskan kegiatannya berdasarkan prinsip Koperasi sekaligus sebagai gerakan } \\
\text { ekonomi rakyat yang berdasar atas asas kekeluargaan }\end{array}$ & $\mathrm{x} .1$ \\
\hline 2 & $\begin{array}{l}\text { Koperasi berlandaskan Pancasila dan Undang-Undang Dasar } 1945 \text { serta berdasar atas asas } \\
\text { kekeluargaan. }\end{array}$ & $\mathrm{x} .2$ \\
\hline 3 & $\begin{array}{l}\text { Koperasi bertujuan memajukan kesejahteraan anggota pada khususnya dan masyarakat pada } \\
\text { umumnya serta ikut membangun tatanan perekonomian nasional dalam rangka mewujudkan } \\
\text { masyarakat yang maju, adil, dan makmur berlandaskan Pancasila dan UUD Dasar } 1945\end{array}$ & x.3 \\
\hline 4 & $\begin{array}{l}\text { Fungsi dan peran Koperasi diantaranya adalah membangun dan mengembang-kan potensi dan } \\
\text { kemampuan ekonomi anggota pada khususnya dan masyarakat pada umumnya untuk } \\
\text { meningkatkan kesejahteraan ekonomi dan sosialnya; }\end{array}$ & $\mathrm{x} .4$ \\
\hline 5 & $\begin{array}{l}\text { Prinsip Koperasi diantaranya adalah keanggotaan bersifat sukarela dan terbuka; pengelolaan } \\
\text { dilakukan secara demokratis; pembagian sisa hasil usaha dilakukan secara adil sebanding } \\
\text { dengan besarnya jasa usaha masing-masing anggota; }\end{array}$ & $\mathrm{x} .5$ \\
\hline 6 & $\begin{array}{l}\text { Kementerian Koperasi dan UMKM terus memperkuat peran koperasi dalam pembiayaan } \\
\text { UMKM, untuk pendukung pengembangan pelaku UMKM }\end{array}$ & x.6 \\
\hline 7 & Koperasi dan UMKM memiliki kontribusi bagi perekonomian di Indonesia & $\mathrm{x.7}$ \\
\hline 8 & $\begin{array}{l}\text { Peran Koperasi di zaman ini semakin meningkat yaitu sebagai organisasi atau lembaga yang } \\
\text { dapat menyediakan lapangan pekerjaan. }\end{array}$ & $\mathrm{x} .8$ \\
\hline 9 & $\begin{array}{l}\text { Koperasi membantu untuk membangun serta mengembangkan potensi ekonomi bagi } \\
\text { anggotanya yang tidak memiliki akses langsung dalam industri keuangan sehingga anggota } \\
\text { dapat terhindar dari praktek rentenir. }\end{array}$ & x.9 \\
\hline 10 & $\begin{array}{l}\text { Pemberdayaan UMKM dan Koperasi merupakan langkah untuk meningkatkan dan memperkuat } \\
\text { dasar kehidupan perekonomian rakyat Indonesia. }\end{array}$ & X.10 \\
\hline 11 & $\begin{array}{l}\text { Koperasi berperan dalam mengembangkan Kegiatan Usaha Masyarakat, dimana anggota } \\
\text { membeli kebutuhan berbagai peralatan dengan harga yang lebih murah. }\end{array}$ & X.11 \\
\hline 12 & $\begin{array}{l}\text { Koperasi juga berperan dalam meningkatkan Taraf Hidup Masyarakat, dengan meningkatkan } \\
\text { penghasilan para anggota koperasi. }\end{array}$ & X.12 \\
\hline 13 & $\begin{array}{l}\text { Koperasi menyediakan layanan untuk menyimpan dana dalam bentuk simpanan wajib dan } \\
\text { sukarela }\end{array}$ & x.13 \\
\hline 14 & Anggota Koperasi adalah pemilik dan sekaligus pengguna jasa Koperasi & x.14 \\
\hline 15 & $\begin{array}{l}\text { Setiap anggota mempunyai kewajiban berpartisipasi dalam kegiatan usaha yang } \\
\text { diselenggarakan oleh Koperasi }\end{array}$ & x.15 \\
\hline 16 & $\begin{array}{l}\text { Setiap anggota mempunyai hak memanfaatkan Koperasi dan mendapat layanan yang sama } \\
\text { antara sesama anggota }\end{array}$ & x.16 \\
\hline
\end{tabular}

\section{HASIL DAN PEMBAHASAN}

Data Deskriptif Peserta

\section{Tabel 3}

Data Deskriptif Peserta

\begin{tabular}{cccc}
\hline \multirow{2}{*}{ Usia Peserta } & $17-25:$ & 20 & $67 \%$ \\
\cline { 2 - 4 } & $26-35:$ & 6 & $20 \%$ \\
\cline { 2 - 4 } & $36-45:$ & 3 & $10 \%$ \\
\cline { 2 - 4 } & $>45:$ & 17 & $3 \%$ \\
\hline \multirow{2}{*}{ Memiliki Usaha } & Memiliki: & 13 & $57 \%$ \\
& Tidak Memiliki: & & \\
\cline { 2 - 4 } & & 2 & $12 \%$ \\
\hline \multirow{2}{*}{ Jenis Usaha } & Toko Kelontong: & 2 & $12 \%$ \\
\cline { 2 - 4 } & Kuliner: &
\end{tabular}




\begin{tabular}{|c|c|c|c|}
\hline & Handicraft: & 8 & $47 \%$ \\
\hline & Toko Fashion: & 3 & $18 \%$ \\
\hline & Lainnya: & 2 & $12 \%$ \\
\hline \multirow[t]{3}{*}{ Jumlah Karyawan } & 2 Orang: & 15 & $88 \%$ \\
\hline & 4 Orang: & 1 & $6 \%$ \\
\hline & 5 Orang: & 1 & $6 \%$ \\
\hline \multirow{4}{*}{$\begin{array}{c}\text { Jumlah Modal } \\
\text { Usaha }\end{array}$} & $<$ Rp.10.000.000,- & 6 & $35 \%$ \\
\hline & Rp.10.000.000,-s/d 25.000.000,- & 11 & $65 \%$ \\
\hline & $>$ Rp.25.000.001,-s/d 50.000.000,- & 0 & $0 \%$ \\
\hline & > Rp.50.000.000,- & 0 & $0 \%$ \\
\hline \multirow[t]{5}{*}{ Sumber Modal } & Sendiri & 15 & $88 \%$ \\
\hline & Pinjaman Keluarga & 2 & $12 \%$ \\
\hline & Pinjaman Bank & 0 & $0 \%$ \\
\hline & Pinjaman Koperasi & 0 & $0 \%$ \\
\hline & Pinjaman Lembaga Lainnya & 0 & $0 \%$ \\
\hline \multirow[t]{4}{*}{ Pendapatan/bulan } & $\leq$ l Juta: & 13 & $76 \%$ \\
\hline & $\geq 1 j t-1,5 j t:$ & 2 & $12 \%$ \\
\hline & $\geq 1,5 j t-2 j t:$ & 1 & $6 \%$ \\
\hline & $\geq 2$ juta: & 1 & $6 \%$ \\
\hline \multirow[t]{4}{*}{ Usia Usaha } & $\leq 2$ Tahun: & 6 & $35 \%$ \\
\hline & > 2-4 Tahun: & 5 & $29 \%$ \\
\hline & $\geq 4-6$ Tahun: & 4 & $24 \%$ \\
\hline & > 6 Tahun: & 2 & $12 \%$ \\
\hline \multirow{4}{*}{$\begin{array}{l}\text { Layanan Koperasi } \\
\text { yang digunakan }\end{array}$} & Simpanan & 2 & $7 \%$ \\
\hline & Pinjaman & 5 & $17 \%$ \\
\hline & Toko Koperasi & 0 & $0 \%$ \\
\hline & Tidak Menggunakan & 23 & $77 \%$ \\
\hline \multirow{2}{*}{$\begin{array}{c}\text { Minat menjadi } \\
\text { Anggota Koperasi }\end{array}$} & Berminat & 24 & $80 \%$ \\
\hline & Belum berminat & 8 & $20 \%$ \\
\hline
\end{tabular}

Berdasarkan data peserta, diketahui usia peserta pelatihan dalam kisaran skala:17-25 tahun sebesar $67 \%$, hal ini menunjukkan bahwa usia peserta berada pada usia produktif. Peserta yang memiliki usaha sebesar: $57 \%$ dan $47 \%$ memiliki usaha berupa kerajinan tangan (handicraft) khas suku baduy, seperti kain tenun, tas koja, souvenir, kain batik. Kegiatan usaha yang dilakukan adalah kegiatan usaha rumahan dengan jumlah karyawan terdiri dari 2 orang sebesar $88 \%$ dengan jumlah modal berada pada skala Rp.10.000.000,- s/d 25.000.000,-sebesar 65\%. Sedangkan sumber dana yang digunakan berupa modal sendiri sebesar $88 \%$, hal ini dikarenakan karakteristik budaya mereka yang tidak ingin terlibat dengan hutang. Dilihat dari pendapatan yang diterima berada pada skala $\leq 1$ Juta sebesar 76\%, hal ini menunjukkan bahwa usaha mereka lebih besar berada pada skala mikro. Usia usaha terbesar berada pada $\leq 2$ tahun sebesar $35 \%$, hal ini menunjukkan bahwa peserta pelatihan merupakan pelaku usaha yang relatif baru. Sedangkan untuk layanan koperasi 77 $\%$ pelaku usaha tidak menggunakan layanan koperasi, hal ini karena mereka menggunakan modal sendiri. Sedangkan minat peserta untuk berpartisipasi sebagai anggota koperasi sebanyak 24 orang (80\%) dan yang belum berminat sebesar 8 orang (20\%). Dengan demikian kegiatan pengabdian kepada masyarakat ini berdampak pada menumbuhkan minat peserta untuk menjadi anggota koperasi. Diharapkan dengan pembekalan dan pendampingan yang berkelanjutan akan lebih menarik minat untuk mendirikan koperasi di desa Kanekes ini. 


\section{Uji Validitas terhadap Butir Pertanyaan}

\section{Tabel 4}

Uji Validitas 16 Butir Pertanyaan

\begin{tabular}{ccccc}
\hline \multicolumn{5}{c}{ Item-Total Statistics } \\
\hline $\begin{array}{c}\text { Butir } \\
\text { Pertanyaan }\end{array}$ & $\begin{array}{c}\text { Scale Mean if } \\
\text { Item Deleted }\end{array}$ & $\begin{array}{c}\text { Scale Variance } \\
\text { if Item Deleted }\end{array}$ & $\begin{array}{c}\text { Corrected Item- } \\
\text { Total Correlation }\end{array}$ & $\begin{array}{c}\text { Cronbach's Alpha } \\
\text { if Item Deleted }\end{array}$ \\
\hline x1 & 51.50 & 33.293 & .092 & .919 \\
\hline x2 & 51.73 & 29.926 & .707 & .902 \\
\hline x3 & 51.77 & 31.633 & .336 & .913 \\
\hline x4 & 51.83 & 28.282 & .690 & .902 \\
\hline x5 & 51.70 & 30.079 & .679 & .903 \\
\hline x6 & 51.83 & 29.799 & .650 & .903 \\
\hline x7 & 51.77 & 30.185 & .659 & .903 \\
\hline x8 & 51.90 & 29.610 & .517 & .909 \\
\hline x9 & 51.70 & 30.493 & .522 & .907 \\
\hline x10 & 51.80 & 30.166 & .668 & .903 \\
\hline x11 & 51.80 & 30.097 & .593 & .906 \\
\hline x12 & 51.83 & 30.282 & .567 & .900 \\
\hline x13 & 51.80 & 29.614 & .774 & .903 \\
\hline x14 & 51.80 & 30.166 & .668 & .899 \\
\hline x15 & 51.83 & 29.523 & .802 & .901 \\
\hline x16 & 51.90 & 29.472 & .732 & . \\
\hline
\end{tabular}

Berdasarkan hasil uji validitas atas $\mathrm{N}: 30, \boldsymbol{\alpha}: 0,05$ dimana $\mathrm{r}$ tabel adalah: 0,3610 dengan demikian terdapat 2 butir pertanyaan yang tidak valid karena $\mathrm{r}$ hitung < dari $\mathrm{r}$ tabel, yaitu butir pertanyaan 1 (x1) dan 3 (x3) dengan demikian butir pertanyaan tersebut dikeluarkan dan tidak digunakan.

Sedangkan hasil uji cronbach alpha sebesar: 0,911 dinyatakan reliabel karena > dari angka minimal yaitu 0,6

Tabel 5

Uji Reliabilitas 16 Butir Pertanyaan

\begin{tabular}{cc}
\multicolumn{2}{c}{ Reliability Statistics } \\
\hline Cronbach's Alpha & N of Items \\
\hline .911 & 16 \\
\hline
\end{tabular}

\section{Tabel 6}

Uji Validitas 14 Butir Pertanyaan

\begin{tabular}{ccccc}
\hline \multicolumn{5}{c}{ Item-Total Statistics } \\
\hline $\begin{array}{c}\text { Butir } \\
\text { Pertanyaan }\end{array}$ & $\begin{array}{c}\text { Scale Mean if } \\
\text { Item Deleted }\end{array}$ & $\begin{array}{c}\text { Scale Variance if } \\
\text { Item Deleted }\end{array}$ & $\begin{array}{c}\text { Corrected Item- } \\
\text { Total Correlation }\end{array}$ & $\begin{array}{c}\text { Cronbach's Alpha } \\
\text { if Item Deleted }\end{array}$ \\
\hline $\mathrm{x} 2$ & 44.53 & 26.947 & .705 & .917 \\
\hline $\mathrm{x} 4$ & 44.63 & 25.826 & .622 & .921 \\
\hline $\mathrm{x} 5$ & 44.50 & 26.948 & .707 & .917 \\
\hline $\mathrm{x} 6$ & 44.63 & 26.792 & .655 & .918 \\
\hline $\mathrm{x} 7$ & 44.57 & 27.151 & .666 & .918 \\
\hline $\mathrm{x} 8$ & 44.70 & 26.493 & .537 & .924 \\
\hline $\mathrm{x} 9$ & 44.50 & 27.155 & .579 & .921 \\
\hline $\mathrm{x} 10$ & 44.60 & 27.145 & .672 & .918 \\
\hline $\mathrm{x} 11$ & 44.60 & 26.938 & .622 & .920 \\
\hline $\mathrm{x} 12$ & 44.63 & 27.068 & .605 & .920 \\
\hline $\mathrm{x} 13$ & 44.60 & 26.731 & .757 & .915 \\
\hline $\mathrm{x} 14$ & 44.60 & 27.214 & .658 & .918 \\
\hline $\mathrm{x} 15$ & 44.63 & 26.654 & .783 & .915 \\
\hline $\mathrm{x} 16$ & 44.70 & 26.493 & .735 & .916 \\
\hline
\end{tabular}




\section{Tabel 7}

Uji Reliabilitas 14 Butir Pertanyaan

\begin{tabular}{cc}
\hline \multicolumn{2}{c}{ Reliability Statistics } \\
\hline Cronbach's Alpha & N of Items \\
\hline .924 & 14 \\
\hline
\end{tabular}

Setelah mengeluarkan 2 buah butir pertanyaan yang tidak valid, dilakukan uji validitas kembali terhadap 14 butir pertanyaan. Hasil uji validitas menunjukkan bahwa semua pertanyaan dinyatakan valid karena $\mathrm{r}$ hitung > r tabel $(0,3610)$ dan berdasarkan uji reliabilitas didapat nilai Cronbach's Alpha sebesar 0,924 yang mempunyai arti bahwa butir pertanyaan dinyatakan reliabel karena nilai Cronbach's Alpha > 0,6 dengan demikian instrumen dapat digunakan sebagai alat penelitian.

\section{Interpretasi Terhadap Pemahaman Peserta Mengenai Peran Koperasi}

\section{Tabel 8}

\section{Interpretasi Pemahaman Terhadap Perkoperasian}

\begin{tabular}{cc}
\hline Skala Penilaian & Intrepretasi \\
\hline $30-52,5$ & Sangat Tidak Paham \\
\hline $52,6-75,1$ & Tidak Paham \\
\hline $75,2-97,7$ & Paham \\
\hline $97,8-120$ & Sangat Paham \\
\hline
\end{tabular}

\section{Tabel 9}

Frekuensi Jawaban Responden

\begin{tabular}{|c|c|c|c|c|c|c|c|c|c|c|c|c|c|c|c|}
\hline \multirow[t]{2}{*}{ Bobot Nilai } & \multicolumn{13}{|c|}{ Frekuensi Jawaban dari Butir Pertanyaan } & \multicolumn{2}{|c|}{$\begin{array}{c}\text { Jumlah } \\
\text { Rata-rata }\end{array}$} \\
\hline & $\mathbf{x 2}$ & $\mathbf{x 4}$ & $\mathbf{x 5}$ & x6 & $\mathbf{x 7}$ & $\mathbf{x 8}$ & $\mathbf{x 9}$ & $\mathbf{x 1 0}$ & $\mathbf{x 1 1}$ & $\mathbf{x 1 2}$ & $\mathbf{x 1 3}$ & $\mathbf{x 1 4}$ & $\mathbf{x 1 5}$ & $\mathbf{x 1 6}$ & \\
\hline 4 & 15 & 15 & 16 & 13 & 14 & 14 & 17 & 13 & 14 & 13 & 13 & 13 & 12 & 11 & \\
\hline 3 & 15 & 13 & 14 & 16 & 16 & 12 & 12 & 17 & 15 & 16 & 17 & 17 & 18 & 18 & \\
\hline 2 & 0 & 1 & 0 & 1 & 0 & 4 & 1 & 0 & 1 & 1 & 0 & 0 & 0 & 1 & \\
\hline 1 & 0 & 1 & 0 & 0 & 0 & 0 & 0 & 0 & 0 & 0 & 0 & 0 & 0 & 0 & \\
\hline $\begin{array}{l}\text { Jumlah } \\
\text { Frekuensi x } \\
\text { Bobot nilai }\end{array}$ & $\begin{array}{l}10 \\
5\end{array}$ & 102 & 106 & 102 & 104 & 100 & 106 & 103 & 103 & 102 & 103 & 103 & 102 & 100 & 103 \\
\hline
\end{tabular}

Berdasarkan data hasil kuesioner menunjukkan nilai rata-rata sebesar 103, yang mempunyai arti bahwa tingkat pemahaman peserta berada pada skala penilaian 97,8-120 yang berarti Sangat Paham dan persentase tingkat pemahaman mencapai sebesar $86 \%$. Hal ini dapat dijelaskan bahwa setelah dilakukan kegiatan pembekalan melalui ceramah, diskusi dan test mengenai pemahaman peserta mengenai peran dan manfaat koperasi, dapat diketahui bahwa peserta sangat memahami peran dan manfaat koperasi bagi anggota dan masyarakat. Dengan demikian bila kegiatan pembekalan ini dapat dilanjutkan dengan pendampingan secara rutin mengenai peran dan manfaat koperasi maka dapat dipastikan pemahaman peserta menjadi lebih tinggi dan dapat memanfaatkan layanan-layanan koperasi.

Selain itu kegiatan ini menumbuhkan minat peserta untuk berpartisipasi sebagai anggota koperasi, hal ini dapat dijelaskan dengan jumlah peserta yang berminat menjadi anggota koperasi sebesar $80 \%$. Untuk itu perlu dilakukan pembekalan secara berkelanjutan agar peserta dapat secara aktif berpartisipasi dalam koperasi dan turut serta dalam pengembangan koperasi. Partisipasi anggota 
koperasi dapat mendorong peningkatan koperasi Indonesia dan mendorong peningkatan kontribusi koperasi dalam perekonomian Indonesia.

\section{Foto Kegiatan}

\section{Gambar 1}

\section{Kegiatan Pembekalan Perkoperasian}

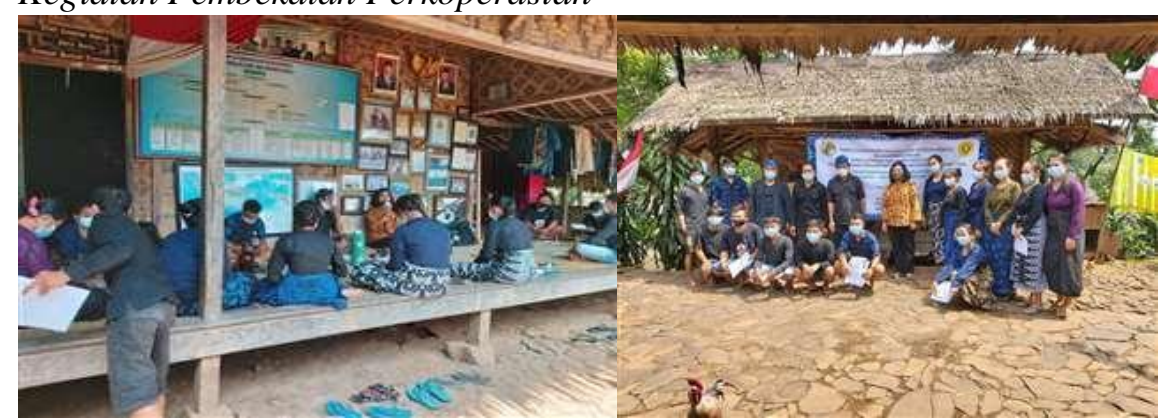

\section{KESIMPULAN DAN SARAN}

\section{Kesimpulan}

Kesimpulan yang dapat diambil dalam pembekalan dan pelatihan perkoperasian dengan tema Pemberdayaan UMKM Melalui Koperasi Pada Kecamatan Leuwidamar, Kabupaten Lebak, Banten adalah usia peserta berada pada usia produktif, serta memiliki usaha berupa kerajinan tangan (handicraft) dengan jumlah karyawan rata-rata sebanyak dua yang merupakan anggota keluarga. Jumlah modal yang dimiliki relatif kecil dan digolongkan sebagai ekonomi mikro. Sedangkan sumber dana yang digunakan berupa modal sendiri dan tidak menggunakan layanan koperasi. Setelah dilakukan pembekalan dan pelatihan mengenai perkoperasian serta dilakukan test untuk pemahaman peran dan manfaat koperasi, hasil yang diperoleh peserta sangat memahami perkoperasian dan berminat untuk berpartisipasi sebagai anggota koperasi.

\section{Saran}

Mengingat koperasi memiliki peran dan berkontribusi terhadap perekonomian di Indonesia, untuk penting diupayakan untuk pengembangan koperasi. Begitu pula dengan UMKM memiliki peran dan berkontribusi dalam PDB Indonesia. Perlu adanya upaya untuk menarik pelaku UMKM untuk ikut serta dan aktif dalam pengembangan koperasi. Dengan turut serta dan berpartisipasi aktif dalam koperasi, pelaku UMKM dapat memperoleh sumber dana untuk menambah modal sebagai dana murah dari koperasi.

Perlu dukungan dari semua pihak, Pemerintah, Swasta dan Institusi Pendidikan Tinggi, untuk bekerjasama dalam pemberdayaan UMKM dan meningkatkan peran koperasi bagi UMKM. Pembekalan dan pelatihan perkoperasian harus dilakukan secara berkelanjutan agar pelaku UMKM dan masyarakat lainnya dapat turut serta dalam pengembangan koperasi sebagai anggota koperasi aktif.

\section{Ucapan Terima Kasih (Acknowledgement)}

Dengan mengucap Puji Syukur kehadirat Allah Yang Maha Kuasa, kegiatan Pengabdian kepada Masyarakat dan artikel dengan judul Pemberdayaan UMKM Melalui Koperasi Pada Kecamatan Leuwidamar, Kabupaten Lebak, Banten telah berhasil diselesaikan. Ucapan terimakasih yang tak terhingga juga kami sampaikan kepada pihak-pihak yang turut mendukung terlaksananya kegiatan ini yaitu kepada Dr. Erna Hernawati, Ak.,CPMA.,CA, selaku Rektor UPN Veteran Jakarta, Dr. 
Retno Dyah Kusumastuti, M.Si selaku ketua LPPM UPN Veteran Jakarta, Dr Dianwicaksih Arieftiara, SE.,AK.,A.Ak.,CA.,CSRS selaku dekan FEB UPN Veteran Jakarta, Drs. H. Babay Imrony, M.Si selaku Kepala Dinas Koperasi dan UMKM Rangkasbitung dan Bpk Saija, Jaro Desa Kanekes.

\section{REFERENSI}

Kadir, H., \& Yusuf, Y. (2012). Optimalisasi pengaruh dan eksistensi koperasi sebagai soko guru perekonomian daerah. Jurnal Ekonomi, 20(3), 1-9. http://dx.doi.org/10.31258/je.20.03.p.\%25p

Mulyono, F. (2010). Mengembangkan koperasi sebagai pemberdaya ekonomi rakyat Indonesia. Jurnal Administrasi Bisnis, 6(1), 1-21. https://doi.org/10.26593/jab.v6i1.368.\%25p

Multi Inti Sarana Group. (2019, September 18). Peran penting koperasi dalam pembangunan ekonomi di Indonesia. https://multiintisarana.com/2019/09/18/peran-penting-koperasidalam-pembangunan-ekonomi-di-indonesia/

Mustangin, Islami, N. P., Kusniawati, D., Setyaningrum, B., \& Prasetyawati, E. (2018). Hasil pemberdayaan masyarakat oleh koperasi sebagai upaya mewujudkan kesejahteraan masyarakat petani daerah Cepogo. Share Social Work Journal, 8(1), 46-54. https://doi.org/10.24198/share.v8i1.16343

Nailufar, N. N. (2020, Maret 23). Koperasi: Pengertian, fungsi, prinsip, dan asasnya. Kompas.com. https://www.kompas.com/skola/read/2020/03/23/140000169/koperasi-pengertian-fungsiprinsip-dan-asasnya?page $=$ all

Niaga.Asia. (2019, November 14). Tahun 2018, kontribusi koperasi terhadap PDB 5,1 persen. Niaga.Asia. $\quad$ https://www.niaga.asia/tahun-2018-kontribusi-koperasi-terhadap-pdb-51persen/

Prasetyo, A. (2018, Juli 13). Kontribusi koperasi meningkat. Media Indonesia. https://mediaindonesia.com/ekonomi/171760/kontribusi-koperasi-meningkat

Rachmawati, A. R. (2019). Kontribusi koperasi terhadap PDB capai 5,1\%. PikiranRakyat.com. https://www.pikiran-rakyat.com/ekonomi/pr-01314265/kontribusi-koperasi-terhadap-pdbcapai-51

Rufaidah, E. (2017). Pemberdayaan perekonomian masyarakat melalui koperasi unit desa berbasis usaha terbimbing. Akademika: Jurnal Pemikiran Islam, 22(2), 361-374. https://ejournal.metrouniv.ac.id/index.php/akademika/article/view/824

Setiawan, S. R. D. (2018, Juli 11). Globalisasi, pisau bermata dua untuk ekonomi Indonesia. Kompas.com. https://ekonomi.kompas.com/read/2018/07/11/074003226/globalisasi-pisaubermata-dua-untuk-ekonomi-indonesia?page=all

Sitepu, C. F., \& Hasyim. (2018). Perkembangan ekonomi koperasi di Indonesia. Niagawan, 7(2). https://doi.org/10.24114/niaga.v7i2.10751

Sukidjo. (2008). Membangun citra koperasi Indonesia. Jurnal Ekonomi \& Pendidikan, 5(2), 194203.

Susilawetty, \& Supena, K. (2013). Peran koperasi serba usaha mutiara mandiri untuk meningkatkan perekonomian masyarakat Gunung Sindur Kabupaten Bogor. Jurnal Ilmiah Widya, $\quad 1(1), \quad 22-30 . \quad$ https://e-journal.jurwidyakop3.com/index.php/jurnalilmiah/article/view/104

Undang-Undang No. 25 Tahun 1992 Tentang Perkoperasian. (1992). Indonesia. https://jdih.kemenkeu.go.id/fulltext/1992/25TAHUN 1992UU.htm\#: :text=UNDANG\%2 DUNDANG\%20TENTANG\%20PERKOPERASIAN.\&text=Dalam\%20Undang\%2Dunda ng\%20ini\%20yang,yang\%20berdasar\%20atas\%20asas\%20kekeluargaan. 